\title{
PROMOTION OF CORPORATE GOVERNANCE FOR SUSTAINABLE FOREST DEVELOPMENT IN SRI LANKA
}

\author{
Mangala De Zoysa and Chamin Fernando \\ Faculty of Agriculture, University of Ruhuna
}

Forestry offers many market and non-market benefits of subsistence needs, commercial production and environmental services. The forests in Sri Lanka are used by many while managed by a few. Hence, the arrangement to govern the multiple interests and needs of different stakeholders have to be clearly defined or understood. Otherwise, there will be a little change in livelihood of forest communities and further degrade the remaining forest resources. The key elements of corporate governance are the transparent and equitable relationships between stakeholders, accountability and participatory decision making.

The papers discuss the problematic issues affecting forest development; the role of corporate governance in forest development; and the impacts of improving governance on sustainable forest development. The major problematic issues are described in terms of the nature of forest resources and the nature of the ownership. The major roles of corporate governance are recognized as: the reforms of administrative and political body that make and implement foresiry and environmental laws; the way these bodies represent and are accountable to forest communities and civil society; and the arrangements that enable forest communities and civil society to enter into dialogue with the government. The impacts of improving corporate governance would be the balanced power and decision-making between central government and local government; promoted relationship between government and forest communities; and developed relationships within the forest communities

Proceedings of the Ninth Annual Forestry and Environment Symposium 2003 of the Department of Forestry and Environmental Science, University of Sri Jayewardenepura. Sri Lanka 